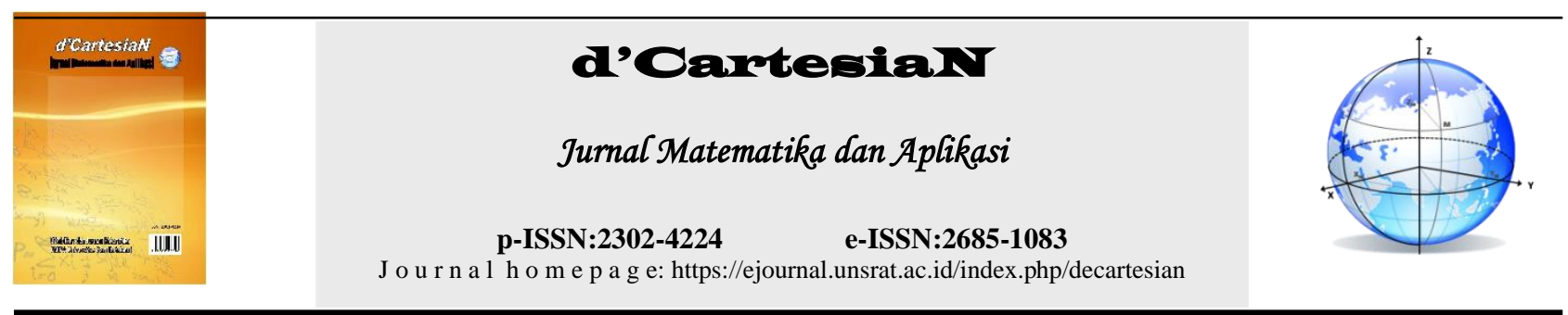

\title{
Automorfisma Graf Lolipop
}

\section{Juwita Fransiska Mandey', Mans Mananohas' ${ }^{1}$, Chriestie Montolalu ${ }^{\text {1* }}$}

${ }^{1}$ Jurusan Matematika-Fakultas Matematika dan Ilmu Pengetahuan Alam-Universitas Sam Ratulangi Manado, Indonesia

${ }^{*}$ Corresponding Author : $\underline{\text { Chriestelly@unsrat.ac.id }}$

\section{ABSTRAK}

Salah satu topik yang menarik untuk di kaji pada teori graf adalah tentang automorfisma graf. Automorfisma graf adalah permutasi graf ke dirinya sendiri dan selalu menghasilkan dirinya sendiri. Akan ditunjukkan apakah automorfisma beberapa unit dari graf lolipop yaitu graf Lolipop $\mathrm{L}_{3,1}, \mathrm{~L}_{4,1}$ dan $\mathrm{L}_{5,1}$ akan membentuk grup dengan menggunakan operasi fungsi komposisi. Hasil penelitian menunjukkan bahwa automorfisma dari ketiga graf tersebut membentuk grup oleh karena memenuhi sifat-sifat grup yaitu tertutup, asosiatif, ada elemen identitas dan ada invers dilihat dari tabel fungsi komposisi masing-masing graf. Juga menunjukkan banyaknya fungsi automorfisma graf lolipop $\mathrm{L}_{\mathrm{n}, 1}$ adalah $\mathrm{n}-1$ !.

\section{INFO ARTIKEL}

Diterima : 22 Januari 2020 Diterima setelah revisi : 24 Januari 2020

Tersedia online : 25 Januari 2020

Kata Kunci

Automorfisma

Graf Lolipop

\begin{abstract}
One of the interesting topics to study in graph theory is about graph automorphism. A graph automorphism is a permutation of a graph to itself and always produces itself. It will be shown whether the automorphism of some units of the lollipop graph namely $\mathrm{L}_{3,1}, \mathrm{~L}_{4,1}$ and $\mathrm{L}_{5,1}$ Lollipop graph will form groups using the composition function operations. The results showed that the automorphism of the three graphs formed a group because it fulfilled the group's characteristics namely closed, associative, there was an identity element and there was an inverse seen from the composition function table of each graph. Also shows the number of graphical automorphic functions of Lollipop $L_{n, 1}$ is $n-1$ !
\end{abstract}

\section{ARTICLE INFO}

Accepted : 22 January 2020 Accepted after revision: 24 January 2020

Available online: 25 January 2020

\section{Keyword}

Automorphism

Lollipop Graph

\section{PENDAHULUAN}

Teori graf diperkenalkan pertama kali tahun 1736 oleh seorang matematikawan asal Swiss yang bernama Leonard Euler melalui karya tulisnya "Seven Bridges of Königsberg". Ia menggunakan teori graf untuk menyelesaikan masalah jembatan Konigsberg (sekarang bernama Kaliningrad). Dari permasalahan itu akhirnya Euler mengembangkan beberapa konsep mengenai teori graf. Masalah tersebut digambarkan melalui titik dan sisi yang menghubungkan antar titik, yang akhirnya berkembang dan dikenal sebagai Graf. Graf didefinisikan sebagai himpunan titik (vertex) yang tidak kosong dan himpunan garis atau sisi (edge) yang mungkin kosong. Himpunan dari suatu graf G dinyatakan dengan $\mathrm{V}(\mathrm{G})$ dan himpunan sisi di nyatakan dengan E(G). Salah satu topik yang menarik untuk dikaji pada teori graf adalah tentang automorfisma graf. Automorfisma graf adalah permutasi graf ke dirinya sendiri dan selalu menghasilkan dirinya sendiri. Graf lolipop ini sendiri masih tergolong graf yang cukup baru dan karena memiliki nama yang cukup unik menjadi menarik untuk dikaji. Data yang di gunakan di mulai dengan menggambarkan tiga graf lolipop yaitu graf Lolipop $\mathrm{L}_{3,1}, \mathrm{~L}_{4,1}$, dan $\mathrm{L}_{5,1}$

\section{PENGERTIAN FUNGSI, GRUP DAN AUTOMORFISMA}

\subsection{Fungsi}

Misalkan $X$ dan $Y$ adalah dua himpunan tak kosong, maka fungsi atau pemetaan dari $X$ ke $Y$ adalah suatu korespondensi yang menghubungkan setiap elemen $\mathrm{x}$ dari $X$ ke suatu elemen tunggal di nyatakan $f(x)$ dari $Y$ dan di tulis:

$$
\mathrm{f}: f: X \rightarrow Y
$$

Yang berarti bahwa $\mathrm{F}$ adalah pemetaan dari $X$ ke $Y$. Elemen $f(\mathrm{x})$ dari Y terhubung dengan elemen $\mathrm{x}$ dari $X$ disebut image dari $\mathrm{x}$ atau bayangan dari $\mathrm{x}$, sedangkan $\mathrm{x}$ disebut pre-image dari $f(x)$. [1].

\subsection{Grup}

Secara umum Grup di definisikan sebagai suatu himpunan tak kosong $\mathrm{G}$ bersama dengan suatu operasi * pada G di namakan Grup terhadap operasi * bila memenuhi aksiomatik grup :

1. Tertutup untuk setiap $\mathrm{a}, \mathrm{b} \in \mathrm{G}$ berlaku $\mathrm{a} * \mathrm{~b} \in \mathrm{G}$. 
2. Assosiatif untuk setiap a, b, c $\in$ G berlaku a * (b * $\mathrm{c})=(\mathrm{a} * \mathrm{~b}) * \mathrm{c}$.

3. Identitas. Ada suatu elemen e $\in \mathrm{G}$ sedemikian hingga untuk semua $a \in G$ berlaku $a * e=a=e^{*}$ a. elemen e dinamakan elemen identitas di G.

4. Invers. Untuk setiap $\mathrm{a} \in \mathrm{G}$ ada elemen $\mathrm{a}^{-1} \in \mathrm{G}$ yang memenuhi $\mathrm{a}^{*} \mathrm{a}^{-1}=\mathrm{e}=\mathrm{a}^{-1} *$ a. Elemen $\mathrm{a}^{-1}$ dinamakan invers dari elemen a. [2]

\subsection{Grup Simetri}

Sebuah permutasi dari suatu himpunan tak kosong adalah pemetaan satu-satu dan pada dari himpunan tersebut. Semua permutasi himpunan tersebut membentuk grup yang disebut grup simetri [3]

\subsection{Graf}

Graf merupakan struktur diskrit yang terdiri dari dua himpunan, yaitu himpunan sejumlah berhingga objek yang disebut titik (vertices,vertex) dan himpunan sisi (edges) yang menghubungkan titik-titik tersebut [4]).

Graf digunakan untuk mempresentasikan objekobjek diskrit dan hubungan antara objek-objek tersebut. Graf $\mathrm{G}$ adalah pasangan (V(G),E(G)) dengan V(G) himpunan tidak kosong dan berhingga dari objek-objek yang disebut titik, dan $\mathrm{E}(\mathrm{G})$ himpunan (mungkin kosong) pasangan tak berurutan dari titik-titik berbeda di V(G) yang disebut sisi [5].

\subsection{Graf Lengkap}

Graf lengkap (Complete Graph) adalah graf yang setiap dua titik yang saling berbeda saling terhubung langsung. Graf komplit dengan $\mathrm{n}$ titik di notasikan sebagai $K_{n}[6]$

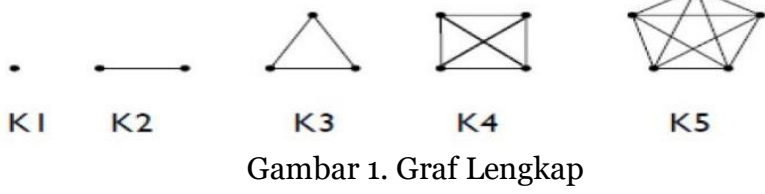

\subsection{Graf Lintasan}

Graf lintasan adalah graf yang terdiri dari sebuah lintasan tunggal. Graf lintasan dengan $n$ vertex di lambangkan oleh Pn. Perhatikan bahwa Pn memiliki ntepi, dan dapat diperoleh dari graf siklus Cn dengan menghapus sebuah sisi seperti yang terlihat pada gambar 2 [6].

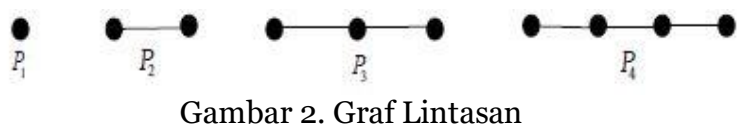

\subsection{Graf Lolipop}

Graf lolipop adalah graf yang diperoleh dengan cara menghubungkan graf lengkap $K_{n}$ dengan graf lintasan $P_{n}$ dengan suatu jembatan (sisi) dan dinotasikan dengan $\mathrm{L}_{\mathrm{m}, \mathrm{n}}$ seperti yang di tunjukkan oleh gambar 3 [7].

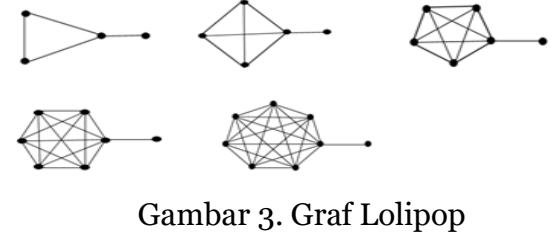

\subsection{Isomorfisme Graf}

Dua buah graf $\mathrm{G}_{1}$ dan $\mathrm{G}_{2}$ dikatakan isomorfik jika terdapat pemetaan satu-satu $\varphi$ antara $V\left(\mathrm{G}_{1}\right)$ pada $\mathrm{V}\left(\mathrm{G}_{2}\right)$ sedemikian hingga misal uv $\in \mathrm{E}\left(\mathrm{G}_{1}\right)$ jika dan hanya jika ( $\varphi(\mathrm{u}) \varphi(v) \in E\left(\mathrm{G}_{2}\right)$. Jika $\mathrm{G}_{1}$ isomorfis terhadap $\mathrm{G}_{2}$ dapat dikatakan bahwa $\mathrm{G}_{1}$ dan $\mathrm{G}_{2}$ saling isomorfik dan dapat di tulis $\mathrm{G}_{1} \cong \mathrm{G}_{2}[8]$.

\subsection{Automorfisma Graf}

Automorfisma pada suatu graf $G$ adalah isomorfisme dari graf $\mathrm{G}$ ke graf $\mathrm{G}$ itu sendiri. Dengan kata lain automorfisma graf $G$ merupakan suatu permutasi dari himpunan titik-titik V(G) [8]

\section{METODOLOGI}

Adapun langkah-langkah yang digunakan oleh penulis dalam membahas penelitian ini adalah sebagai berikut :

1. Memilih data yang digunakan dalam hal ini data graf lolipop.

2. Menganalisa data yang meliputi langkah-langkah berikut :

a. Menggambarkan graf lolipop $\mathrm{L}_{3,1}, \mathrm{~L}_{4,1}$, dan $\mathrm{L}_{5,1}$.

b. Memberikan label pada setiap titik dari masingmasing graf yang telah digambarkan pada bagian a.

c. Menentukan semua kemungkinan permutasi dari setiap graf pada dirinya sendiri dari bagian b

d. Memilah permutasi yang automorfisma dan yang tidak automorfisma dari semua kemungkinan fungsi yang telah dituliskan pada bagian c.

e. Menentukkan karakteristik automorfisma

f. Menunjukkan bahwa himpunan automorfisma dari graf lolipop dengan operasi komposisi adalah membentuk grup.

3. Membuat kesimpulan.

\section{HASIL DAN PEMBAHASAN}

\subsection{Automorfisma Pada Graf Lolipop}

Hasil dan pembahasan akan dimulai dari penggambaran grafnya secara umum kemudian pemberian label pada titik titiknya dan menentukan semua kemungkinan fungsi yang satu-satu dan pada berbentuk permutasi dari graf yang sudah diberi label kemudian memilah-milah fungsi permutasi yang automorfisma dan yang bukan automorfisma lalu menentukan dan membuktikan teorema yang di bangun dari hasil automorfisma graf tersebut. Beberapa dari graf lolipop yang di bahas adalah
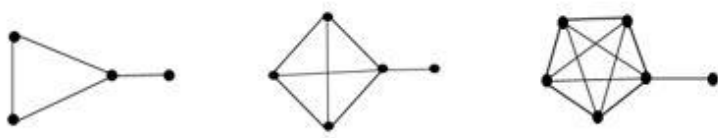

Gambar 4. Graf Lolipop $\mathrm{L}_{3,1}, \mathrm{~L}_{4,1}$ dan $\mathrm{L}_{5,1}$ 
Selanjutnya akan diberikan label untuk masingmasing titik pada graf-graf tersebut seperti pada gambar 5

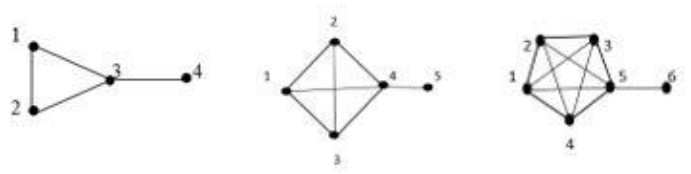

Gambar 5. Graf Lolipop $\mathrm{L}_{3,1}, \mathrm{~L}_{4,1}$ dan $\mathrm{L}_{5,1}$ dengan label titik

Kemudian akan ditentukan fungsi automorfisma yang dapat dibuat dari masing-masing graf tersebut. Langkah ini dimulai dengan dari graf Lolipop $\mathrm{L}_{3,1}$ sebagai berikut:

\subsubsection{Graf Lolipop $\mathrm{L}_{3,1}$}

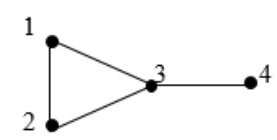

Gambar 6. Graf Lolipop $\mathrm{L}_{3,1}$

Himpunan titik pada graf Lolipop dimisalkan sebagai $\mathrm{V}\left(\mathrm{L}_{3,1}\right)=\{1,2,3,4\}$. Diberikan suatu fungsi dari Lolipop $\mathrm{L}_{3,1}$ pada dirinya sendiri yaitu $\varphi: \mathrm{V}\left(\mathrm{L}_{3,1}\right) \rightarrow$ $\mathrm{V}\left(\mathrm{L}_{3,1}\right)$.

Banyaknya semua kemungkinan fungsi yang 1-1 dan pada dari Lolipop $\mathrm{L}_{3,1}$ kepada dirinya sendiri sebanyak 24 fungsi. Dan dari fungsi-fungsi tersebut hanya ada 2 fungsi yang automorfisma yaitu

1. $\varphi_{1}=(1)(2)(3)(4)$

Dapat dilihat dari fungsi ini bahwa $\varphi_{1}(1)=1, \varphi_{1}(2)$ $=2, \varphi_{1}(3)=3, \varphi_{1}(4)=4$. Jika menggunakan tabel maka dapat dinyatakan dengan

Tabel 1. Permutasi $\varphi_{1}$

\begin{tabular}{lllll}
$\mathrm{vi}_{\mathrm{i}}$ & 1 & 2 & 3 & 4 \\
\hline$\varphi\left(v_{i}\right)$ & 1 & 2 & 3 & 4
\end{tabular}

Terlihat graf hasil fungsinya seperti pada gambar 7

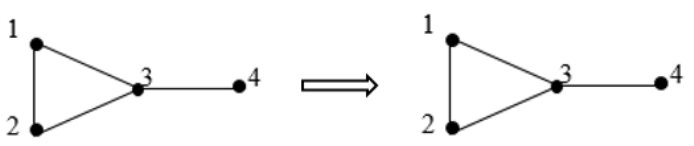

Gambar 7. Graf Lolipop $\mathrm{L}_{3,1}$ dengan $\varphi_{1}=$ (1) (2) (3) (4)

Fungsi $\varphi_{1}=(1)(2)(3)(4)$ adalah automorfisma karena pada graf awalnya dapat dilihat bahwa sisi $(1,3) \in \mathrm{E}\left(\mathrm{L}_{3,1}\right)$ maka $(\varphi(1), \varphi(3))=(1,3) \in \mathrm{E}\left(\mathrm{L}_{3,1}\right)$ (Kodomain). Artinya terdapat sisi $(1,3)$ pada graf itu sendiri. Begitu pula untuk sisi $(1,2)$, sisi $(2,3)$ dan sisi $(3,4) \in \mathrm{E}\left(\mathrm{L}_{3,1}\right)$. Jadi fungsi identitas adalah automorfisma.

2. $\varphi_{2}=(3)(4)(12)$
Dapat dilihat dari fungsi ini bahwa $\varphi_{2}(1)=2, \varphi_{2}(2)$ $=1, \varphi_{2}(3)=3, \varphi_{2}(4)=4$. Jika menggunakan tabel maka dapat dinyatakan dengan

Tabel 2. Permutasi $\varphi_{2}$

\begin{tabular}{lllll}
$\mathrm{V}_{\mathrm{i}}$ & 1 & 2 & 3 & 4 \\
\hline$\varphi\left(v_{i}\right)$ & 2 & 1 & 3 & 4
\end{tabular}

Dan graf hasil fungsinya dapat dilihat seperti pada gambar 8

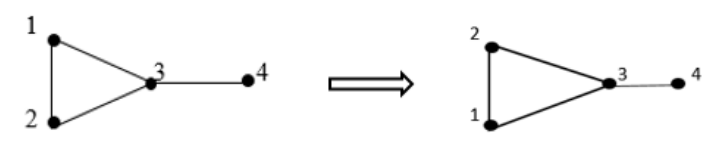

Gambar 8. Graf Lolipop $\mathrm{L}_{3,1}$ dengan $\varphi_{2}=(3)$ (4) (1 2)

Fungsi $\varphi_{2}=(3)$ (4) (1 2) adalah automorfisma karena pada graf awalnya dapat diperlihatkan bahwa sisi $(2,3) \in\left(\mathrm{L}_{3,1}\right)$ maka $(\varphi(2), \varphi(3))=(1,3) \in \mathrm{E}\left(\mathrm{L}_{3,1}\right)$ (Kodomain). Artinya terdapat sisi $(1,3)$ pada graf itu sendiri. Begitu pula untuk sisi $(1,2)$, sisi $(1,3)$ dan sisi $(3,4) \in \mathrm{E}\left(\mathrm{L}_{3,1}\right)$.

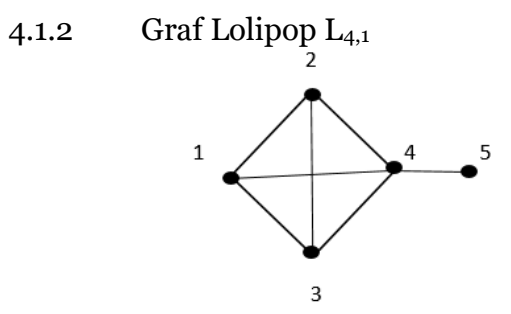

Gambar 9. Graf Lolipop $\mathrm{L}_{4,1}$

Himpunan titik pada graf lollipop $\mathrm{L}_{4,1}$ dimisalkan $\mathrm{V}\left(\mathrm{L}_{4,1}\right)=\{1,2,3,4,5\}$. Di berikan suatu fungsi dari graf Lolipop $\mathrm{L}_{4,1}$ pada dirinya sendiri yaitu $\varphi$ $: \mathrm{V}\left(\mathrm{L}_{4,1}\right) \rightarrow \mathrm{V}\left(\mathrm{L}_{4,1}\right)$. Banyaknya semua kemungkinan fungsi yang 1-1 dan pada dari Lolipop L4,1 kepada dirinya sendiri sebanyak 120 fungsi. Akan tetapi, dari fungsi fungsi tersebut hanya ada 6 fungsi yang automorfisma yaitu :

\section{1. $\varphi_{1}=(2)(4)(5)\left(\begin{array}{ll}1 & 3\end{array}\right)$}

Fungsi $\varphi_{2}=(1)(4)(5)(1 \quad 3)$ adalah automorfisma karena pada graf awalnya dapat diperlihatkan bahwa sisi $(2,4) \in \mathrm{E}\left(\mathrm{L}_{4,1}\right)$ menjadi $\left(\varphi_{2}(2)=3, \varphi_{2}(3)=2\right)$. Dimana bisa dilihat pada graf asalnya bahwa sisi $(3,2) \in \mathrm{E}\left(\mathrm{L}_{4,1}\right)$. Begitu pula untuk sisi sisi lainnya.

Dari fungsi ini dapat dilihat bahwa $\varphi_{3}(1)=3, \varphi_{3}(2)$ $=2, \varphi_{3}(3)=1, \varphi_{3}(4)=4, \varphi_{3}(5)=5$. Bila dilihat melalui tabel dapat dinyatakan dengan

Tabel 3. Permutasi $\varphi_{1}$

\begin{tabular}{llllll}
$\mathrm{V}_{\mathrm{i}}$ & 1 & 2 & 3 & 4 & 5 \\
\hline$\varphi\left(v_{i}\right)$ & 3 & 2 & 1 & 4 & 5
\end{tabular}

Dan graf hasil fungsinya dapat dilihat seperti pada gambar 10 


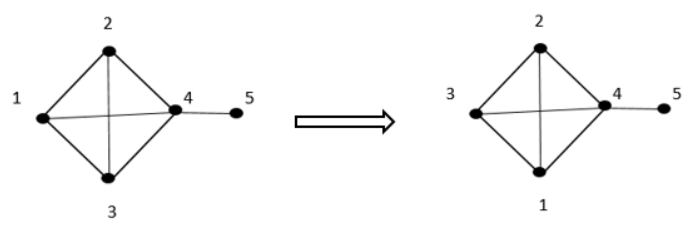

Gambar 10. Graf Lolipop L4,1 dengan graf $\varphi_{1}$

$$
\text { 2. } \varphi_{2}=(1)(4)(5)(23)
$$

Dari fungsi ini dapat dilihat bahwa $\varphi_{2}(1)=1$, $\varphi_{2}(2)=3, \varphi_{2}(3)=2, \varphi_{2}(4)=4, \varphi_{2}(5)=5$. Bila dilihat melalui tabel dapat dinyatakan dengan

Tabel 4. Permutasi $\varphi_{2}$

$\begin{array}{llllll}\mathrm{V} i & 1 & 2 & 3 & 4 & 5 \\ & & & & & \\ & 1 & 3 & 2 & 4 & 5\end{array}$

Dan graf hasil fungsinya dapat dilihat pada gambar 11

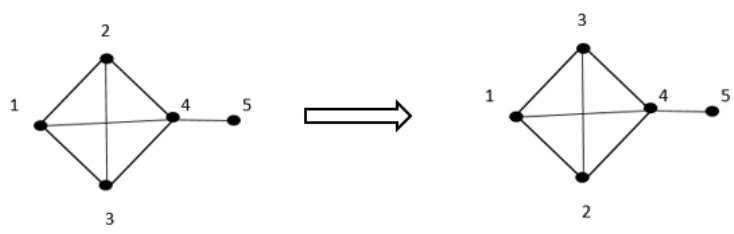

Gambar 11. Graf Lolipop $\mathrm{L}_{4,1}$ dengan graf $\varphi_{2}$

Fungsi $\varphi_{3}=(1)(4)(5)(23)$ adalah automorfisma karena pada graf awalnya dapat diperlihatkan bahwa sisi $(2,4) \in \mathrm{E}\left(\mathrm{L}_{4,1}\right)$ menjadi $\left(\varphi_{2}(2)=3, \varphi_{2}(3)=2\right)$. Di mana bisa dilihat pada graf asalnya bahwa sisi $(3,2) \in \mathrm{E}\left(\mathrm{L}_{4,1}\right)$. Begitu pula untuk sisi sisi lainnya.

Hal yang sama berlaku juga untuk fungsi fungsi yang automorfisma lainnya dibawah ini yaitu

$$
\begin{aligned}
& \varphi_{3}=(1)(2)(3)(4)(5) \quad \varphi_{5}=(4)(5)(1 \quad 2 \quad 3) \\
& \varphi_{4}=(3)(4)(5)(1 \quad 2) \quad \varphi_{6}=(4)(5)(1 \quad 3 \quad 2)
\end{aligned}
$$

4.1.3 Graf Lolipop $\mathrm{L}_{5,1}$

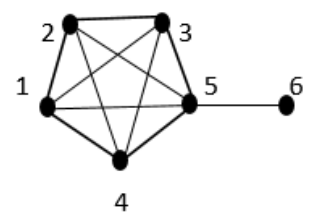

Gambar 12. Graf Lolipop $\mathrm{L}_{5,1}$

Himpunan titik pada graf lollipop $\mathrm{L}_{5,1}$ dimisalkan $\mathrm{V}\left(\mathrm{L}_{5,1}\right)=\{1,2,3,4,5,6\}$. Di berikan suatu fungsi dari graf Lolipop $\mathrm{L}_{5,1}$ pada dirinya sendiri yaitu $\varphi: \mathrm{V}\left(\mathrm{L}_{5,1}\right) \rightarrow$ $\mathrm{V}\left(\mathrm{L}_{5,1}\right)$. Banyaknya semua kemungkinan fungsi yang 1-1 dan onto dari Lolipop $\mathrm{L}_{5,1}$ kepada dirinya sendiri sebanyak 720 fungsi. Akan tetapi, dari fungsi fungsi tersebut hanya ada 24 fungsi yang automorfisma yaitu :
Dari fungsi ini dapat dilihat bahwa $\varphi_{1}(1)=3, \varphi_{1}(2)$ $=2, \varphi_{1}(3)=1, \varphi_{1}(4)=4, \varphi_{1}(5)=5$ dan $\varphi_{1}(6)=6$. Bila dilihat melalui tabel dapat dinyatakan dengan

Tabel 5. Permutasi $\varphi_{3}$

\begin{tabular}{lllllll}
$\mathrm{vi}_{\mathrm{i}}$ & 1 & 2 & 3 & 4 & 5 & 6 \\
\hline$\varphi\left(v_{i}\right)$ & 1 & 2 & 4 & 3 & 5 & 6 \\
\hline
\end{tabular}

Dan graf hasil fungsinya dapat dilihat pada gambar 13
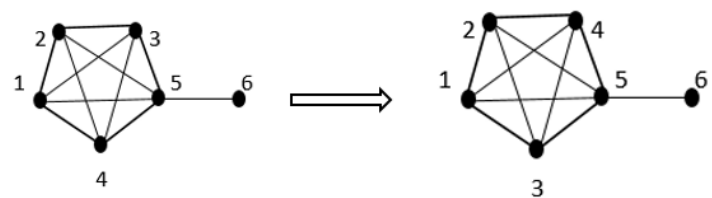

Gambar 13. Graf Lolipop $\mathrm{L}_{5,1}$ dengan $\varphi_{1}$

Fungsi $\varphi_{3}=$ (1) (2) (5) (6) (3 4) adalah automorfisma karena pada graf awalnya dapat diperlihatkan bahwa sisi $(3,5) \in \mathrm{E}\left(\mathrm{L}_{5,1}\right)$ menjadi $\left(\varphi_{1}(3)=\right.$ $\left.4, \varphi_{1}(5)=5\right)$. Di mana bisa dilihat pada graf asalnya bahwa sisi $(4,5) \in E\left(L_{5,1}\right)$. Begitu pula untuk sisi sisi lainnya.

$$
\text { 2. } \varphi_{2}=\left(\begin{array}{ll}
1 & 2
\end{array}\right)(34)(5)(6)
$$

Dari fungsi ini dapat dilihat bahwa $\varphi_{2}(1)=2, \varphi_{2}(2)$ $=1, \varphi_{2}(3)=4, \varphi_{2}(4)=3, \varphi_{2}(5)=5$ dan $\varphi_{2}(6)=6$. Bila dilihat melalui tabel dapat dinyatakan dengan

Tabel 6. Permutasi $\varphi_{2}$

\begin{tabular}{lllllll}
$\mathrm{vi}_{\mathrm{i}}$ & 1 & 2 & 3 & 4 & 5 & 6 \\
\hline$\varphi\left(v_{i}\right)$ & 2 & 1 & 4 & 3 & 5 & 6 \\
\hline
\end{tabular}

Dan graf hasil fungsinya dapat dilihat seperti dibawah ini

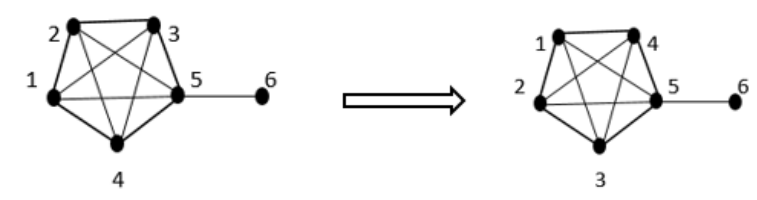

Gambar 14. Graf Lolipop $\mathrm{L}_{5,1}$ dengan $\varphi_{2}$

Fungsi $\varphi_{2}=\left(\begin{array}{ll}1 & 2\end{array}\right)(34)(5)(6)$ adalah autmorfisma karena pada graf awalnya dapat diperlihatkan bahwa sisi $(1,4) \in$ $\mathrm{E}\left(\mathrm{L}_{5,1}\right)$ menjadi $\left(\varphi_{2}(1)=2, \varphi_{2}(4)=3\right)$. Dimana bisa dilihat pada graf asalnya bahwa sisi $(2,3) \in \mathrm{E}\left(\mathrm{L}_{5,1}\right)$. Begitu pula untuk sisi sisi lainnya. 
Fungsi-fungsi lainnya yang automorfisma :

$$
\begin{aligned}
& \varphi_{1}=(1)(2)(3)(4)(5)(6) \quad \varphi_{7}=(2)(4)(5)(6)(13) \quad \varphi_{11}=(2)(5)(6)(134) \\
& \varphi_{4}=(1)(3)(5)(6)(24) \quad \varphi_{8}=(3)(4)(5)(6)(12) \quad \varphi_{12}=(2)(5)(6)(143) \\
& \varphi_{5}=(1)(4)(5)(6)(23) \quad \varphi_{9}=(1)(5)(6)(234) \quad \varphi_{13}=(3)(5)(6)(124) \\
& \varphi_{6}=(2)(3)(5)(6)(14) \quad \varphi_{10}=(1)(5)(6)(243) \quad \varphi_{14}=(3)(5)(6)(142) \\
& \varphi_{15}=(4)(5)(6)\left(\begin{array}{lll}
1 & 2 & 3
\end{array}\right) \quad \varphi_{19}=(5)(6)(13324) \quad \varphi_{23}=(5)(6)(13)(24) \\
& \varphi_{16}=(4)(5)(6)\left(\begin{array}{lll}
1 & 3 & 2
\end{array}\right) \quad \varphi_{20}=(5)(6)\left(\begin{array}{lll}
1 & 3 & 4
\end{array}\right) \quad \varphi_{24}=(5)(6)(14)(23) \\
& \varphi_{17}=(5)(6)\left(\begin{array}{llll}
1 & 2 & 3 & 4
\end{array}\right) \quad \varphi_{21}=(5)(6)\left(\begin{array}{llll}
1 & 4 & 2 & 3
\end{array}\right) \\
& \varphi_{18}=(5)(6)\left(\begin{array}{llll}
1 & 2 & 4 & 3
\end{array}\right) \quad \varphi_{22}=(5)(6)\left(\begin{array}{llll}
1 & 4 & 3 & 2
\end{array}\right)
\end{aligned}
$$

\begin{tabular}{|c|c|c|c|}
\hline Graf Lolipop L $\mathrm{L}_{3,1}$ & Graf Lolipop $\mathrm{L}_{4,1}$ & Graf Lolipop $\mathrm{L}_{5}$, & \\
\hline$(3)(4)().()=1$. & $(4)(5)().().()=1$. & $(5)(6)().().().()$. & $=1$ \\
\hline \multirow[t]{4}{*}{$(3)(4)(.)=1}$. & $(4)(5)().(.)=3$. & $(5)(6)().().(.)$. & $=6$ \\
\hline & $(4)(5)(\ldots)=2$ & $(5)(6)().(\ldots)$ & $=8$ \\
\hline & & $(5)(6)(\ldots)$. & $=6$ \\
\hline & & $(5)(6)(.).(.)$. & $=3$ \\
\hline 2 Fungsi & 6 fungsi & 24 fungsi & \\
\hline
\end{tabular}

\subsection{Pola Titik Fungsi Automorfisma}

Selanjutnya akan di tentukan banyaknya fungsi yang automorfisma dari masing-masing graf berdasarkan bentuk-bentuk permutasi yang mengacu pada pemetaan titik-titiknya yang memenuhi fungsi tersebut dalam bentuk pola umum sebagai berikut :

Banyaknya fungsi automorfisma pada graf lolipop $\mathrm{L}_{3,1}$ adalah sebanyak 2 fungsi.

Banyaknya fungsi automorfisma pada graf lolipop $\mathrm{L}_{4,1}$ adalah sebanyak 6 fungsi.

Banyaknya fungsi automorfisma pada graf lolipop $\mathrm{L}_{5,1}$ adalah sebanyak 24 fungsi.

Banyaknya fungsi automorfisma pada graf lolipop $\mathrm{L}_{6,1}$ adalah sebanyak 120 fungsi.

Banyaknya fungsi automorfisma pada graf lolipop $\mathrm{L}_{7,1}$ adalah sebanyak 720 fungsi.

Dari uraian diatas maka berdasarkan banyaknya titik dapat dibuat teorema tentang banyaknya automorfisma dari graf lollipop $L_{n, 1}$ yaitu sebagai berikut :

\section{Teorema 1}

Banyaknya fungsi automorfisma pada graf lolipop $L_{n, 1}$ adalah $\mathrm{n}-1$ !.

\subsection{Fungsi Automorfisma membentuk grup}

\begin{tabular}{|c|c|c|}
\hline & $o \quad(1)(2)(3)(4)$ & $(12)(3)(4)$ \\
\hline$(1)(2)(3)(4)$ & $(1)(2)(3)(4)$ & $(12)(3)(4)$ \\
\hline$(12)(3)(4)$ & $(12)(3)(4)$ & $(1)(2)(3)(4)$ \\
\hline
\end{tabular}

Selanjutnya akan ditunjukkan apakah semua himpunan fungsi yang automorfisma membentuk grup atau tidak menggunakan fungsi komposisi. Dari tabel dibawah bisa dilihat bahwa himpunan fungsi Automorfisma graf lolipop $\mathrm{L}_{3,1}$, graf lolipop $\mathrm{L}_{4,1}$ dan graf lollipop $\mathrm{L}_{5,1}$ membentuk grup .

Tabel 8. Tabel Fungsi Komposisi Automorfisma Graf Lolipop
Tabel 9. Tabel Fungsi Komposisi Automorfisma Graf Lolipop $\mathrm{L}_{4,1}$

\begin{tabular}{lllllll}
$r$ & $(1)(2)(3)($ & $(1)(4)(5$ & $(2)(4)(5$ & $(3)(4)(5$ & $(4)(5)(1$ & $(4)(5)(1$ \\
& $4)(5)$ & )$(23)$ & )$(13)$ & )$(12)$ & $23)$ & $32)$ \\
\hline$(1)(2)(3$ & $(1)(2)(3$ & $(1)(4)(5$ & $(2)(4)(5$ & $(3)(4)(5$ & $(4)(5)(1$ & $(4)(5)(1$ \\
)$(4)(5)$ & )$(4)(5)$ & )$(23)$ & )$(13)$ & )$(12)$ & $23)$ & $32)$ \\
$(1)(4)(5$ & $(1)(4)(5$ & $(1)(2)(3$ & $(4)(5)(1$ & $(4)(5)(1$ & $(2)(4)(5$ & $(3)(4)(5$ \\
)$(23)$ & )$(23)$ & )$(4)(5)$ & $23)$ & $32)$ & )$(13)$ & )$(12)$ \\
$(2)(4)(5$ & $(2)(4)(5$ & $(4)(5)(1$ & $(1)(2)(3$ & $(4)(5)(1$ & $(3)(4)(5$ & $1)(4)(5)(2$ \\
)$(13)$ & )$(13)$ & $32)$ & )$(4)(5)$ & $23)$ & )$(12)$ & \\
$(3)(4)(5$ & $(3)(4)(5$ & $(4)(5)(1$ & $(4)(5)(1$ & $(1)(2)(3$ & $(1)(4)(5$ & $(2)(4)(5$ \\
)$(12)$ & )$(12)$ & $23)$ & $32)$ & )$(4)(5)$ & )$(23)$ & )$(13)$ \\
$(4)(5)(1$ & $(4)(5)(1$ & $(3)(4)(5$ & $(1)(4)(5$ & $(2)(4)(5$ & $(4)(5)(1$ & $(1)(2)(3$ \\
$23)$ & $23)(1)$ & )$(12)$ & )$(23)$ & )$(13)$ & $32)$ & )$(4)(5)(5)$ \\
$(4)(5)(1$ & $(4)(5)(1$ & $(2)(4)(5$ & $(3)(4)(5$ & $(1)(4)(5$ & $(1)(2)(3$ & $(4)(5)(1$ \\
$32)$ & $32)$ & )$(13)$ & )$(12)$ & )$(23)$ & )$(4)(5)$ & $23)$ \\
\hline
\end{tabular}

Tabel 10. Tabel Komposisi Fungsi Graf Lolipop $\mathrm{L}_{5,1}$

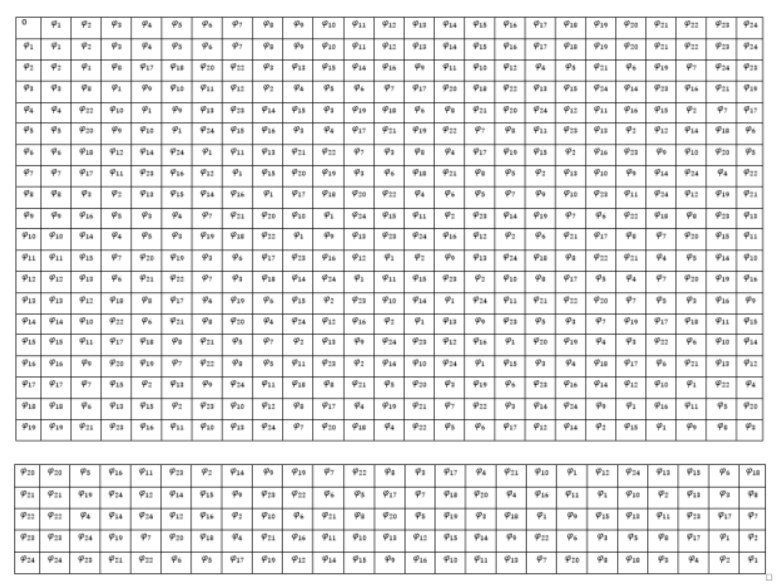

\section{KESIMPULAN DAN SARAN}

\subsection{Kesimpulan}

Berdasarkan pembahasan, dapat ditarik kesimpulan bahwa :

1. himpunan fungsi automorfisma dari masing-masing graf tersebut adalah membentuk grup karena memenuhi sifat-sifat grup yaitu tertutup, Asosiatif, ada elemen identitas, dan ada invers dilihat dari tabel fungsi komposisi graf lolipop $\mathrm{L}_{3,1}$, graf lolipop $\mathrm{L}_{4,1}$, graf lolipop $\mathrm{L}_{5,1}$.

2. Banyaknya fungsi automorfisma dari graf lolipop $L_{n, 1}$ adalah n-1!

\subsection{Saran}

Penelitian ini hanya terbatas pada graf lolipop $\mathrm{L}_{3,1}$, $\mathrm{L}_{4,1}$ dan $\mathrm{L}_{5,1}$. Bisa di lakukan penelitian selanjutnya dengan membahas sampai pada automorfisma graf Lolipop $\mathrm{L}_{\mathrm{m}, \mathrm{n}}$ dan graf-graf yang lainnya.

\section{REFERENSI}

[1] Raisinghania, M.D dan Aggrawal, R.S. 1980. Modern Algebra. Ram Nagar, New Delhi

[2] Subiono. 2015. Aljabar : Sebagai Suatu Pondasi Matematika. Surabaya : FMIPA ITS

[3] Joyce, D. 2017. Introduction to Modern Algebra. Clark University, Massachusetts

[4] Shofiyatul, Hasanah. 2007. Aplikasi Pewarnaan Graf Terhadap Penjadwalan Kuliah Matematika UIN Malang. Malang : UIN Malang

[5] Abdussakir, Nilna Niswatin A. 2009. Teori Graf. UIN Malang, Malang

[6] Wilson, R.J dan Watkins, J.J. 1990. Graphs An 
Introductory Approach. Canada : John Wiley and Sons, Inc.

[7] Chandrasekaran, S. dan Kanimozhi, K. 2019. Perfect Domination Polynomial for Lollipop Graph. Khadir Mohideen College, Adirampattinam

[8] Chartrand, G dan Lesniak, L. 1986. Graph and Digraphs Second Edition. Mc Graw-Hill Inc, California

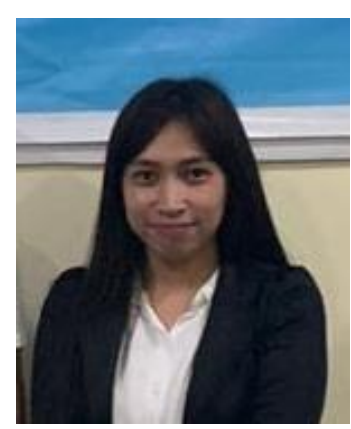

Juwita

F.

(Jumonday777@gmail.com)

Lahir di Noongan, 7 Juni 1992. Menempuh pendidikan tinggi Jurusan Matematika, FMIPA, Universitas Sam Ratulangi Manado. Tahun 2020 adalah tahun terakhir ia menempuh studi. Makalah ini merupakan hasil penelitian skripsinya yang dipublikasikan.

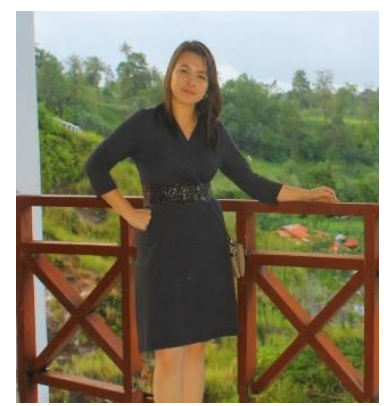

Chriestie Montolalu

(Chriestelly@unsrat.ac.id)

Lahir di Tomohon, 10 Desember 1983. Pada tahun 2015 memperoleh gelar Magister Sains (M.Sc) dari Queensland University. Menjadi pengajar tetap di Jurusan Matematika, Fakultas Matematika dan Ilmu Pengetahuan Alam Universitas Sam Ratulangi Manado.

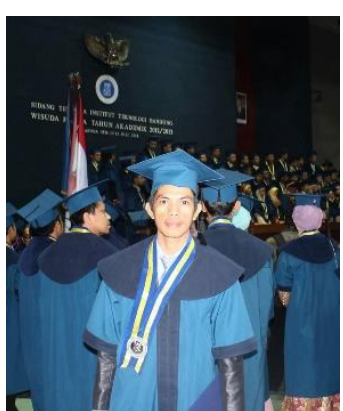

Mans Mananohas

(mansmananohas@unsrat.ac.id) Lahir di Ambon, 11 Juni 1984. Pada tahun 2013 memperoleh gelar Magister Sains (M.Si) dari Institut Teknologi Bandung. Menjadi pengajar tetap di Jurusan Matematika, Fakultas Matematika dan Ilmu Pengetahuan Alam Universitas Sam Ratulangi Manado. 